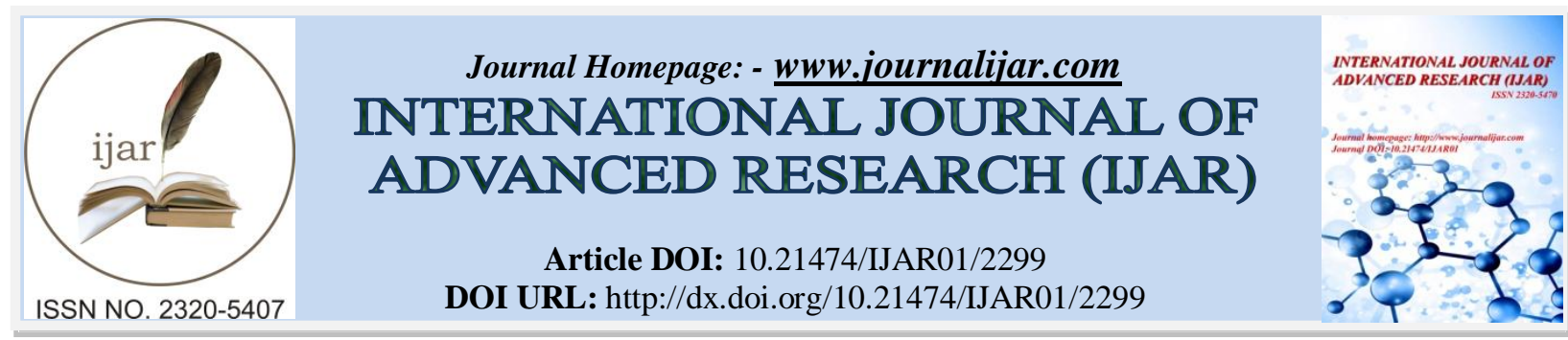

RESEARCH ARTICLE

\title{
GUARDIANSHIP BY RULER IN FINANCIAL ISSUES AND ITS IMPLEMENTATION: AN ANALYSIS BASED ON THE CALIPHATE OF UMAR (MAY ALLAH BE PLEASED WITH HIM).
}

Dr. Mufti Imran ul Haq Kalyanvi.

Assistant Professor, Department of Quran-o-Sunnah, University of Karachi, Karachi, Pakistan.

\section{Manuscript Info}

Manuscript History

Received: 29 September 2016

Final Accepted: 30 October 2016

Published: November 2016

Key words:-

Guardianship, caliph, Umar, ruler, responsibility

\section{Abstract}

The healthy relationship of ruler and subjects creates peace and harmony in the society. In Islam there are several instructions for both the ruler and subjects because of their inseparability. However, being authority the ruler has a great responsibility of providing financial assistance especially to the poor, needy, orphans, immigrants, handicapped and the disabled etc. In this way instead of becoming a burden on the society these people can play an important role in its development.

The purpose of this study is to explore the concept of guardianship for the rulers that has been designed by Islam in order to make a good relationship between the rulers and their subjects. Although the guardianship is a wide issue and there are several aspects of guardianship. However, this manuscript focuses on the Islamic teachings regarding guardianship for the rulers in terms of financial assistance and especially during the period of Hazrat Umar (R.A). As he used different strategies to overcome financial issues, therefore, the manuscript identifies the major policies that have been implemented for the proper guardianship of the people during the reign of Hazrat Umar (R.A).

Copy Right, IJAR, 2016,. All rights reserved.

\section{Introduction:-}

Islam emphasis on mutual relationship, rights and responsibilities as such a living would promote mutual compassion and love. It would definitely create a healthy and peaceful society. Actually it is the policy of give and take, disturbance in any of the two can't maintain peace and security in a society. Every individual of society needs basic livelihood i.e. food, water, shelter and clothing but it is impossible for individuals to arrange all these necessities. Therefore, Allah the almighty has arranged a balanced system of rights and responsibilities. Sometimes parents are liable for the proper nourishment of their children while sometimes children are responsible to spend on their parents. In case of the guardianship, generally Allah the almighty made it obligatory on the ruler of that society. The ruler has a great responsibility of guardianship regarding the poor, needy, orphans, immigrants, handicapped and the disabled etc.

The Prophet Muhammad (peace and blessings of Allah be upon him) once said:

"Every one of you is a shepherd and is answerable with regard to his subject. The Caliph of a state is a shepherd over the people and he will be questioned about it (e.g. how he conducted the affairs of his subjects). A man is a custodian over his family members and will be questioned about them (e.g. how he looked after them in overall matters of their lives). A woman is responsible for the household of husband and children and she will be questioned 
about her responsibilities (e.g. how she managed the family affairs and brought up her children). A slave is a custodian over his master's property and will be inquired about it. (e.g. how he watched over his trust). Be cautious, everybody is a guardian and everybody will be questioned about his/her trust."(1)

\section{Distinctions of $\operatorname{Umar}$ (R.A.):-}

It is his distinction that while other companions of the Prophet embraced Islam themselves, the Prophet had prayed to Allah to strengthen Islam with Umar (R.A.) and to give it success under his leadership.

When he was appointed at the post of caliphate he had tremendous experience in affairs of government having been a minister with the Prophet (peace and blessings of Allah be upon him).

He was the Ameer (head) of the department of justice and the advisor-in-chief in the Siddiqi's era. He had become capable of running and resolving government affairs after many years of experience.

The Prophet (peace and blessings of Allah be upon him) had said, Follow Abu Bakar (R.A.) after me and Umar (R.A.) after him. All the companions of the Prophet also held this opinion that he was the most suited for the Ummah (nation) after Hazrat Abu Bakar (R.A.) (2) and often his decisions were confirmed by the verses of the Quran(3).

\section{The Caliphate of Umar (R.A.):-}

He led the government for ten years and six months and this era of the second caliph is considered as the 'Golden Era' of the Islamic world. He was so conscious of his responsibilities that man aside, he was cautious about the animals. As he used to say that he will be answerable to Allah if a camel(4) or animal(5) dies because of hunger at the seashore.

Such a ruler can surely never neglect his subjects, he may go hungry himself but he cannot bear to see his people in starvation.

\section{The Main Source of Financial Assistance:-}

In order to make a balanced system in the society and to provide financial assistance to his subjects he properly maintained the system of Bait-ul-Maal literally Bait-ul-Maal means the house of the wealth. However, it can be considered as a safe and secure compound to place the treasury of the State. The system that Umar (R.A.) introduced was based on a Central State Treasury (CST) and some other local treasuries. The CST was in Madina and Hazrat Abdullah Ibn Arqam (R.A.) was its administrator. Many provincial treasuries were created under the CST and their administrators were subordinates of Abdullah Ibn Arqam (R.A.).

Instead of preserving the wealth in the CST, Umar (R.A.) used to distribute it among the deserving people(6). During his reign when the treasures of Caesar and Kisra including the buried ones were shifted to Madina even then he did not think to safe and preserve it for long lasting. He did not care to save them that he might prolong his rule or find them useful in gaining victories over other people. However, the amount to pay salaries was preserved in CST.

\section{His Concern for Guardianship:-}

Umar (R.A.) had a great sense of responsibility and the strategy he has adopted to help his people was based on a direct link with them. He openly invited the needy people by saying, whoever wants financial assistance, come to me because Allah had me liable and distributor over the treasure(7). Once when he was addressing to his people he said: "Allah has made me responsible to stop supplications from going to Him."(8)

Apart from his concerns to the general public he has established some policies to support different people in different circumstances and some of them are discussed here in short.

\section{For Guests and Travelers:-}

Umar (R.A.) was not only conscious of guardianship over his subjects; he had also made official arrangements for the guests and travelers. In many cities inns were built and the travelers had facilities of boarding and lodging. Even the meals were at government's expenses. For this purpose 'Umar (R.A.) had created a department for food. It 
stored flour, parched barley, dates, currants and other such items which were provided when necessary to the travelers and those who were lost their way'.(9)

The guest house at Madina was open for all and the host was not anyone else but the caliph himself. It was in his routine that after the Isha prayer he meets the guests and asks them whether they had their meal or not. If he found anyone hungry there then he himself arranges food for him.

\section{During Famine:-}

During the reign of Umar (R.A.) the most severe famine struck Northern Arab. Umar (R.A.) swore that he would not eat ghee, yogurt or milk until all the people could afford to have these things. Some ghee and yogurt reached the marketplace and a slave bought it for Umar (R.A.) for 40 dirhams. He came to Umar (R.A.) and said: "O, commander of the faithful, Allah has fulfilled your oath and made your reward great. Some ghee and yogurt came to the marketplace and I bought it for you for 40 dirhams." Umar (R.A) said, "You paid too much for it give it in charity, for I do not like to eat in an extravagant manner." And Umar (R.A.) said, "How could I care for the people properly if I do not feel what they feel?" (10) and he (R.A.) refrained from eating fat or fatty food for a year(11).

The famine was experienced in 18 A.H and $\operatorname{Umar}$ (R.A.) demonstrated extremely wise policies to deal with it. He provided his subject with grain and ordered the governors to send supplies. The governor of Egypt, Amr Ibn al-Aas (R.A.) replied, "I am sending so many grain-laden camels."(12) Hazrat Umar (R.A.) instructed him to send via sea route at the port of Jaar so that the common Muslim may have enough(13). Amr Ibn al-Aas (R.A.) sent twenty shiploads via the Red-Sea. Hazrat Umar (R.A.) went to the port with some other companions (R.A.) to receive the consignment. He handed over the grain to the responsible man and ordered to arrange two warehouses there. He instructed Hazrat Zayd Ibn Tabit (R.A.) to write down the names of the people according to their rank(14). In this way he handled the worst famine and provided food to his subject.

\section{Solution for Handicapped:-}

He had issue orders for regular stipends for the destitute and poor handicapped. There were more than hundreds of thousands of men enlisted and they got all of their food stuff regularly. The quantity of wheat necessary was calculated and each one whether citizen or villager was allotted accordingly(15). He climbed up the pulpit with a scoop in his hand and told his audience that he had fixed a particular quantity of food according to their requirement and if anyone minimizes the quantity then he will be accountable to Allah(16).

Those people who could not come to the capital city were sent their share at home on monthly basis(17). The provision included flour and dates. Villagers were sent camels laden with the provision.

It is of interest to know that during the famine. Hazrat Umar (R.A.) had enforced allowances on a fixed basis (or rationing). He did not do it in the cool atmosphere of an office, but he worked out the average per person requirement after due practical calculation. If everyone got enough to fill his stomach then no one would resort to corruption or black-market. If a physical or mental worker did not get what he needed to eat then his working would be hampered, lowering national wealth and the country would fall into poverty and backwardness(18).

According to one version, he said:

"I have allotted for each Muslim two mudd wheat and two qist vinegar. Someone interjected, "Is that also for a slave?" He said, "Yes, for a slave and the poor too." (19)

\section{Clothing, Housing and Construction:-}

When the wealth of the state treasury was enough, Hazrat Umar (R.A.) also distributed clothing to the people. He built for them brick houses which were airy. New cities were created at Kufa, Basra and Fustat with the wide roads, shops and roundabouts. Separate areas were marked out as camels-stands. Tributaries were created from rivers to channel water to cities. In this way, every citizen had food, clothing and home. We can see that it was more than 1400 years ago that the budget of an Islamic State had proviso for benefits to the unemployed, handicapped and the poor. In contrast, law for such benefits was passed in Britain in 1901 C.E., the (laterday) Beveridge scheme is known for that (20).

For Non-Muslims:-

Different governments have different ideas of social schemes for their citizen. The Beveridge report was much talked about during World War II but was not put into practice with much sincerity. Many of his proposals were 
borrowed from the social scheme of Hazrat Umar (R.A.) which had been in practice in his times and was available to everyone without distinction, even the non-Muslims(21). Zakah was collected from the rich Muslims for the upkeep of the helpless Muslims. As for receipts under the head of Jizyah, Kharaj and import(22).

Umar Ibn Nafi reported that while Hazrat Umar (R.A.) was passing through someone's door once, he saw an old blind man beg of men. He held his shoulder and asked him what his religion was, and why did he beg? He answered, "I am a Jew, I beg because I am handicapped and I have to pay the Jizyah." Hazrat Umar (R.A.) took him by the hand to his home and gave what he had to give. He then summoned the administrator of the state treasury and instructed him to search for such people and give them maintenance from the treasury.

"Look out for this man and others like him (non-Muslims). We cannot be fair if we take from them their earnings (Jizyah) when they are young but leave them to be disgraced in old age to beg."(23) As the Holy Quran says:

"The alms are for the poor and the needy..."(24)

I think the poor are the deserving among Muslims while the needy are the needy among the people of the Book. He also waived the Jizyah on the old, blind man and others like him.

While he was in Syria he came across a group of Christians afflicted by leprosy on the route to Damascus. He gave orders that they should be given help from the state treasury and an allowance be allotted to them(25).

His words, "take their earnings of you youth but leave them disgraced in old age", are worth pondering over. Just as governments take taxes, they must also provide benefits when people are destitute. It is wrong to tax when they are wealth but leave them in the lurch when they are old and weak(26).

The guardianship of non-Muslim and the policy of not burdening them is not exclusive to Umar's (R.A.) era but it is part of the Islamic economic policy. Every living soul within its borders should not be deprived of basic necessities of life. No one must be burdened only because he is non-Muslim. In fact, the small Jizyah that is taken from against protection extended to them is taken only from the earning male members. It is not taken from slaves, women or children(27). In short, Islam's economic policy binds the government to support all its subjects particularly those worthy of mercy without distinction of religion and descent and a separate head of account is created for that (28).

\section{Supporting Infants:-}

Once Hazrat Umar (R.A.) came across an infant who was crying in it's mother's lap. He asked its mother to see to its need, but when he returned through the same place, the child was still crying. He scolded the mother, saying, "You are merciless." But she said, "You do not know the facts and scold me for no fault of mine. The truth is that Umar (R.A.) has passed orders not to allot a stipend to a child who has not been weaned (that is, as long as it takes mother's milk). That is why I wish to wean it and it cries for the milk. Hazrat Umar (R.A.) was taken over by emotion and exclaimed, "Alas! Umar, you have the blood of many children over you! "The same day, he proclaimed that a child's allowance will be given from the very day it is born(29).

\section{Orphans and Illegitimate Children:-}

The state treasury was responsible to support children without parents or of unknown parents. If a child had no father, or if it had been abandoned on a thoroughfare, then it was brought to the Amee-ul-Mumineen. He would fix a hundred dirham for the child and as much as was necessary for its upkeep. The guardian of the child would collect the amount from the treasury every month. The Ameer-ul-Mumineen would go and see the child every year and commend proper care of the child(30). The state was responsible for an unclaimed child's upbringing. This is what Hazrat Umar (R.A.) and Hazrat Ali (R.A.) reported.

For, such a child is a Muslim who is unable to earn, has no wealth and no relatives(31). Same rules apply as are applicable to an heirless and wealth-less crippled for his maintenance. The argument is that the inheritance of the unclaimed is deposited in the state Treasury. So, the receiver expends(32).

\section{Children of Warriors:-}

Every child of the participants of the Battle of Qadsiyah without exception received a stipend. Khalid Ibn Urfutah al-Uzri met Hazrat Umar (R.A.), he asked, "How are they whom you have left behind?" He said, "They pray to Allah that we should add their life span to yours. Of those who overran Qadsiyah there is none who does not get two thousand or one and a half thousand (dinars)! Even male and female children do not go without a hundred dirham 
monthly." He said that is their right which I give them. If this had belonged to Khattab (my father) I would never have parted from it. I know that the grant exceeds their needs. If each one of them buys a goat when he gets the grant then that will increase his aptitude and his offspring will never be empty-handed thereafter. He will have something of the wealth remaining with him(33).

\section{Muslim Women}

Hazrat Umar (R.A.) had apportioned twelve thousand dinars for the Mother's of the believers, one thousand dinars for the earliest female Muhajirs and they include Hazrat Asma bint Umays (R.A.) and Asma bint Abu Bakr (R.A.) and the mother of Ibn Masood(34).

Hisham al-Ka'bi said that he saw Hazrat Umar (R.A.) carry the register of the treasury up to Qudayd. Women and men gathered round him and he gave the grant to each of them one by one. Next he would go to Usfaan and do the same thing. He practiced this till he died(35).

\section{Imam, Muazzin and Teachers:-}

It is only in the preaching of Islam that lays its glory and sustainability. A separate department should be set aside for it, and that should always be active in discharging this duty. As for those people who devote their lives entirely to this task with sincerity and selflessness so that they give up all worldly occupation and do not find time to earn their own living, the state must take responsibility for them and their families. This would enable them to carry on their obligations uninterrupted and without anxiety. Imam Ibn Jawzi (R.A) has reported in Seerats at Umarayn:

"Indeed Umar (R.A.) and Usman (R.A.) used to provide honorarium to the Mu'azzins, Imams and teachers (each month)." Abu Ubayd Qasim Ibn Salaam and Allamah Zayl'ee have stated in Kitab al-Amwaal and Nash ar-Raiyah respectively that Hazrat Umar (R.A.) wrote to his officers:

"The teachers of the Quran may be giving a reward." (36)

There is another interpretation of the Arabic words of this saying, "An allowance should be appointed to those who study the Quran." An argument in support of this interpretation is that the governors wrote back to him that some people have become students of the Quran only to receive the allowance without the actual inclination. But, Hazrat Umar (R.A.) did not discontinue the allowance(37) because of nobility, compassion, love and respect.

\section{Dual Grant to the Married People:-}

It was the Prophet's (Peace be upon him) practice that when he received the wealth from $F a^{\prime} i$ he disbursed it that very day, and he was particular to give two shares to a married man and one to the single. Hazrat Umar (R.A.) gave away the wealth of $f a^{\prime} i$ and every single individual got half a dinar and he who had a wife got one dinar(38).

\section{Relatives of the Sahabah-e-Karam:-}

Aslam reported that he was with Hazrat Umar (R.A.) a village woman came to him. She said, "O Ameer-ulMumineen! I am the daughter of Khafaf Ibn Ayma (R.A.) who participated in the battle of Hudaybiyah with Allah's Messenger (Peace be upon him)." Hazrat Umar (R.A.) said, "This is a close relationship", and he gave instructions that she should be provided enough to meet the expenses for her meals and clothing(39). According to a version a man died within eight months of a year. Umar (R.A.) allotted him two-thirds of the annual allowance(40).

\section{Umar's (R.A.) Future Plans:-}

It was Umar's (R.A.) earnest desire that every individual in his domain should get his/her share easily. He said: "If I am alive then every Muslim, even the shepherd in San'a, Yemen would be delivered his share directly."(41) Once when he was discussing his future plan he said: By Allah, if I live, I will surely leave behind the Iraqi window in such a position that they will not have to depend on an Ameer anymore."(42)

\section{Conclusion:-}

It is obvious from these disclosures that Islam has not chosen the rulers to suck the blood of their subjects. Rather, it binds them to ensure economic support to every individual. The ruler is bound to arrange for support and maintenance for men, women, young, old, Muslims, non-Muslims and even animals.

However, nowadays many rulers spend lavishly on their trips to foreign lands, tens of millions rupees on each trip. They appropriate the wealth of the masses and enact laws but do not know anything else, not even how to enforce the laws. The poor do not get two square meals and though every member of the house works they get involved 
deeper and deeper into debt. Or, if they get a house then they are constantly under obligation of the House Building finance corporation to repay their loan.

How good it would be if they spend the money instead on the poor! How many people would be happy and lead a comfortable life. We believe that propagation and spread of Islam depends on sincerity, good deeds, unity and the willingness to sacrifice life in the way of Allah. In fact it was due to Umar's (R.A.) practical approach rather than emotional speeches that Islamic teachings illuminated Syria, Iraq, Iran and Egypt. Today many of the Muslim states need such a ruler for the survival of not only Islam and Muslims but for the whole mankind.

\section{References:-}

1. Muslim, Imam. (2007). "English Translation of Sahih Muslim", Vol. 5, Riyadh: Darussalam, p. 155

2. Ez-ud-Deen bin Al Aser, "Asad ul Ghaba fi Marfat ul Sahaba”, Vol. 3, Tehran: Maktaba Islamia, p. 220

3. Tafseer Ibn e Kaseer, Tafseer of Verse 125 of Chapter 'The Cow'

4. Ibn-e-Saad, (1957). "Tabqaat-e-Kubra", Vol. 3, Beirut: Dar Sadir, p. 31

5. Ibid, p. 305

6. Imam Abu Yousuf Yaqoob bin Ibrahim, (1382h). "Kitab-ul-Kiraj”, Cairo: Al-Matba As-Salfia, p. 42

7. Balazri, Yahya bin Adam. (1319h). "Futooh ul Buldan", Egypt: Al-Babi Al-Halbi, p. 272

8. Abu Muhammad Azuddin. (1388h). "Qawaid al-Ahkam fi Masalih al-Anam, Cairo: Maktabah al-Kuliyat alAzhariyah

9. Jalal uddin Suyuti. (1983). "Tareekh ul Khulafa", Karachi: Nafees Academy

10. As-Sallabi, Ali Muhammad. (2007). "Umar Ibn Al-Khattab his life and times", International Islamic Publishing House, p. 410

11. Tamir Abu As-Su'ood Muhammad Noha Kamal Ed-Din Abu Al-Yazid, (2001). Biographies of the RightlyGuided Caliphs, Egypt: Dar Al-Matiarah, p. 198

12. Ibn-e-Saad, (1957). "Tabqaat ul Kubra", p. 224

13. Muhammad Yousuf uddin, (1968). "Islam kay Maashi Nazariay", Karachi: Allied Books, p. 482

14. Ahmad Ibn Abu Yaqoob Ibn Wadih al-Katib, "Tareekh e Yaqoobi”, Vol. 2, Laydan, p. 177

15. Muhammad Yousuf uddin, (1968). "Islam kay Maashi Nazariay", Vol. 2, p. 748

16. Balazri, Yahya bin Adam. (1319h). "Futooh ul Buldan", p. 465-466

17. Muhammad Yousuf uddin, (1968). "Islam kay Maashi Nazariay", Vol. 2, p. 483

18. Ibid, p. 379-380

19. Muhammad Saadullah, (1999). "Bunyadi Zaroriyat-e-Zindagi aur Islam", Lahore: Iqbal publishing, p. 339

20. 20 Noor Muhammad Ghaffari, (1989). "Islam ka Qanoon-e-Mahasil”, Lahore: Diyal Singh Trust, p. 140

21. Muhammad Yousuf uddin, (1968). "Islam kay Maashi Nazariay", Vol. 2, p. 440

22. Ibid, p. 754

23. Imam Abu Yousuf Yaqoob bin Ibrahim, (1382h). "Kitab-ul-Kiraj”, p. 126

24. Al Quran 9: 60

25. Balazri, Yahya bin Adam. (1319h). "Futooh-ul-Buldan", p. 465-466

26. Muhammad Yousuf uddin, (1968). "Islam kay Maashi Nazariay", Vol. 2, p. 756

27. Muhammad Saadullah, (1999). "Bunyadi Zaroriyat-e-Zindagi aur Islam", p. 358

28. Noor Muhammad Ghaffari, (1989). "Islam ka Qanoon-e-Mahasil", p. 154

29. Muhammad Saadullah, (1999). "Bunyadi Zaroriyat-e-Zindagi aur Islam”, p. 348

30. Ahmad Ibn Abu Yaqoob Ibn Wadih al-Katib, "Tareekh-e-Yaqoobi", Vol. 2, Laydan, p. 71

31. Shaikh Zain-ud-Din Ibn Abi Yaqoob, "Bahar Al-Raiq", Vol. 5, Quetta: Maktaba Rasheediya, p. 144

32. Muhammad Yousuf uddin, (1968). "Islam kay Maashi Nazariay", Vol. 2, p. 747

33. Ibn-e-Saad, (1957). "Tabqaat-e-Kubra", p. 215

34. Ibid, p. 216

35. Ibid, p. 214

36. Kalyanvi, Imran-ul-Haq. (2000). "Irshad Al-Sahmzai: Nizamuddin Shamzai”, Karachi: Maktaba Kalyanvi, p. 317

37. Hifz-ur-Rahman. (1995). "Islam ka Iqtisadi Nizam”, Lahore: Zahid Basheer Printers, p. 147

38. Abu Ubeed Qasim bin Salam, (1986). "Kitab-ul-Amwal”, Islamabad: Idara Tehqiqat-e-Islami, p. 362

39. Ibid, p. 392

40. Ibid, p. 390

41. Ibid, p. 371

42. Imam Abu Yousuf Yaqoob bin Ibrahim, (1382h). “Kitab-ul-Kiraj”, p. 37 